\title{
REFLEXÕES SOBRE AS COMEMORAÇÕES DO DIA DA MÃE-TERRA NAS NAÇÕES UNIDAS, EM 21 DE ABRIL DE 2017
}

\author{
REFLECTIONS ON MOTHER-EARTH DAY CELEBRATIONS IN THE UNITED \\ NATIONS, ON APRIL 21, 2017
}

\author{
Cristiane Derani \\ Doutora \\ Universidade Federal de Santa Catarina \\ Brasil
}

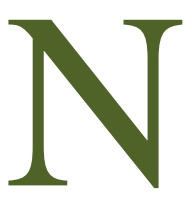

o dia 21 de abril, as Nações Unidas promoveram o diálogo interativo organizado pela

Assembleia Geral sobre a Harmonia com a Natureza, em que se discutiu a aplicação do par. 3 da resolução 71/232 de 21 de dezembro 2016 sobre a Jurisprudência da Terra e as recomendações do relatório externo apresentado na ocasião. O objetivo do evento foi encorajar a sociedade a repensar e redescobrir as relações com o mundo natural e o fundamento ético da relação entre humanidade e a Terra no contexto do desenvolvimento sustentável.
Entre as diversas e ricas deliberações, destaco uma de relevante interesse para o estudioso do Direito, posto ser referente a sua principal ferramenta: a linguagem.

Toda percepção da natureza é uma compreensão humana, social, cultural e historicamente situada. E, como tal, ela encontra na linguagem sua forma de expressão. A linguagem não é um simples vernáculo aleatório, com o qual ideias ganham formato. São arcabouços ideológicos, planos verbais da cultura, expressões de um pensamento historicamente construído. 
A palavra faz pensar ao mesmo tempo em que o pensamento vivo vai à busca de seus nomes. O pensamento se expressa a partir de uma pré-compreensão do significado das palavras. Nas palavras de Merleau-Ponty, «il n’y a pas la pensée et le langage, chacun des deux ordres à examen se dédouble et envoie un rameau dans l'autre». A importância das palavras e seus significados, portanto, são fundamentais para o desdobramento do pensamento e pela interlocução nos diálogos.

A linguagem de proteção do meio ambiente entra no mundo político e jurídico, pela porta das Nações Unidas no final da década de 60 (resolução da Assembleia Geral da ONU, 2398 em 1968) e influencia toda construção subsequente do direito ambiental, em que a própria palavra natureza cede para a ideia de meio "milieu" ,"environment”.

Nesse órgão, em 1972, surge o primeiro documento jurídico de direito ambiental internacional: a Declaração de Estocolmo, cujo vocabulário próprio mostra um predomínio das áreas econômica (recursos naturais, soberania permanente sobre recursos naturais, desenvolvimento econômico, indenização), científica (saúde, saneamento) e de direitos humanos (liberdade, igualdade).
A construção do direito ambiental como novo ramo do direito se faz pela adoção bastante acentuada de uma linguagem econômica, o que contamina todo o conjunto de normas que se desenvolve a partir de então. O vocabulário econômico e seus significados colonizam a percepção da natureza o direito ambiental nascente. A combinação das palavras e seus significados pré constituídos conformam o conteúdo do discurso e a racionalidade que o permeia. Das palavras provêm o seu já estabelecido significado (Wortbegriff). O conceito original permanece e é reproduzido em sua essência, limitando os sujeitos a um universo de expressão préconcebido.

Segundo Merleau-Ponty:

Il y a une signification langagière du langage qui accomplit la mediation entre mon intention encore muette et les mots, de telle sorte que mês paroles me surprennent moi-meme et m'enseignent ma pensée. Les signes organisés ont leur sens imanente, qui ne releve pas du 'je pense, mais du 'je peux'1.

Quando o discurso sobre a natureza adota expressões como meio ambiente e recursos naturais, o todo orgânico interdependente conectado com o ser humano é esvaziado de vida e autonomia.

\footnotetext{
${ }^{1}$ Idem, 111.
} 
Natureza é dissecada e a suas partes inanimadas atribui-se função e utilidade.

É significativa a história de expressões-chave do direito ambiental como recursos naturais e desenvolvimento sustentável. A expressão recursos naturais entra nas Nações Unidas em meio à disputa entre ex-colônias e metrópoles pela exploração econômica daquilo que é visto como valiosa matéria prima para o processo econômico. A discussão sobre o princípio da Soberania Permanente sobre os Recursos Naturais registra a expressão "recurso natural" no léxico das Nações Unidas, no contexto da disputa pela titularidade para exploração.

Natureza, recurso natural, expressa uma compreensão estática, apartada, utilitarista da natureza, a qual se limita a objeto, disputado ambicionado por detentores de território e exploradores estrangeiros. A visão da natureza entra na plataforma ambiental da política internacional pelo viés da livre determinação dos povos e da soberania em explorar seu território e exaurir suas riquezas.

Ao adotar recurso natural, como sinônimo de natureza, fazendo equivaler a ideia de proteção dos recursos naturais à de conservação da natureza, opera-se uma interpretação distorcida da natureza. Por um lado, esposa-se a ideia de Lineu de que os seres vivos podem ser classificados desprovidos de relação com o todo, por outro lado identifica natureza a bem econômico, com um valor-utilidade, a ser apropriado e utilizado nos processos humanos de produção.

Trinta anos após a discussão sobre a soberania permanente sobre os recursos naturais, as Nações Unidas, em sua contínua busca do desenvolvimento de países descolonizados, depara-se com a expressão desenvolvimento sustentável. Expressão essa já presente no vocabulário econômico do pós-guerra, quando era apresentada como objetivo no processo de reconstrução europeia, visando a busca de um crescimento continuado e equilibrado.

No contexto ambiental, esta expressão econômica é trazida pelo relatório encomendado pelo Programa das Nações Unidas para o Meio Ambiente, pulicado em 1987, com o nome Nosso Futuro Comum. A expressão Desenvolvimento Sustentável provém da economia da reconstrução e aceleração do crescimento de uma Europa castigada pelas guerras. Nela, taxas de crescimento da produção, aumento de emprego e equilíbrio da inflação formam seu conteúdo.

Apresentada ao discurso ambiental, o conteúdo econômico pré-existente mimetiza-se com a conservação dos habitats e ecossistemas. A força 
economicista da expressão coloniza o discurso ecológico com a racionalidade econômica e utilitarista. Natureza esvaziada de vida transmuta-se em elemento apropriável, recurso natural que lado a lado com elementos criados pela prática econômica - emprego, produção, consumo - passa a compor um novo organismo, o da economia ambientalmente responsável.

Em conclusão, a linguagem do direito ambiental é inapropriada para designar padrões de vida que subvertam a ordem exploratória e consumista reinante. Há um padrão racional que precisa ser quebrado para que a natureza seja compreendida em sua subjetividade, compreendida como um todo orgânico, dinâmico e integrado do qual o ser humano é componente e dependente. Essa quebra de racionalidade envolve uma modificação radical da linguagem que vem sendo empregada no direito ambiental.

Racionalidade e linguagem desenvolvem-se conectadas e uma não se modifica sem a outra. Daí a importância da mudança de paradigma linguístico na busca de uma nova racionalidade política e jurídica para o tratamento dos processos ecológicos ameaçados pelas ações humanas. A adoção de uma nova linguagem é vital para a política que reverta o curso destrutivo

\footnotetext{
2 « L'intention significative se donne um corps et se connait ele-meme em se cherchant um equivalente dans le systeme des significations disponibles que
}

autoimposto pelos seres humanos de destruição da natureza.

Uma grande transformação do pensar, designar e agir está em curso e com ela a reformulação da linguagem do discurso é inalienável. Um processo de ressignificação ocorre e toma corpo na medida em que novos signos linguísticos são apropriados redefinindo as intenções e reconstruindo a cultura ao mesmo tempo em que dela é herdeiro ${ }^{2}$.

Somos herdeiros de uma cultura iluminista que, durante o século XVIIII, sedimentou a ideia de separação do ser humano da natureza e sua bipartição entre corpo e alma. A reaproximação do ser humano à ideia natureza como grande mãe é, ao mesmo tempo, uma subversão cultural que se constrói ao longo de pelo menos três séculos. A cultura do iluminismo que forjou a ideia de espécie humana deve ser reinventada, e para isso é importante olhar os povos indígenas que se mantiveram refratários ao processo europeu de individualização e desconexão do humano com a natureza.

O ser humano iluminista, homo sapiens, detentor de amplo poder de dominação por ser o único animal com razão e consciência de liberdade, não se

representent la langue que je parle et l'ensemble des écrits et de la culture dont je suis l'heritier ». Idem, 113. 
reconhece como parte e dependente daquilo que pretende submeter. Este homo não é o sujeito histórico natural cultural que encontra no outro seu complemento e na natureza seu suporte e simultânea realização material e espiritual e deve reencontrar-se com sua fonte criadora e colocar-se horizontalmente no conjunto da criação

Da natureza classificável em unidades (Lineu), e do homem histórico que se relaciona com o meio natural como objeto (Buffon), algo deve emergir. $\mathrm{Na}$ razão iluminista, o ser humano é reconhecido como proveniente da natureza, mas dela se separa por ser livre e consciente. Uma reconfiguração da linguagem pelo emprego da consciência livre do ser humano resignificando a relação humana natural-social pode ser construída na atividade política e jurídica. A referência a povos que não sucumbiram ao narcisismo enganador do iluminismo e mantiveram dentro de suas estruturas sociais e normativas a relação horizontal compreensiva e respeitosa com a natureza é fundamental. Novas designações e normas ecológicas reequilibradoras da relação homem e natureza são necessárias. A harmonia com a natureza é uma meta das sociedades que usam da política e do direito para desfazer-se das armadilhas traçadas pelo individualismo e utilitarismo. Para isso o Direito e a Política devem empregar signos e significados compatíveis com a ideia de natureza dinâmica e integrada, dotada de um valor intrínseco, fonte de toda a vida, na qual o ser humano se conecta e dela depende. 